\title{
Microsatellite markers in analysis of resistance to coffee leaf miner in Arabica coffee
}

\author{
Gabriella Santos Pereira(1), Lilian Padilha(2), Edila Vilela Resende Von Pinho(1), \\ Rita de Kássia Siqueira Teixeira( ${ }^{(1)}$, Carlos Henrique Siqueira de Carvalho(2), Mirian Peres Maluf(2) \\ and Bruna Line de Carvalho ${ }^{(1)}$
}

(1)Universidade Federal de Lavras, Caixa Postal 3037, CEP 37200-000 Lavras, MG, Brazil. E-mail: gabipereira87@yahoo.com.br, edila@dag.ufla.br, ritaaadekassia@hotmail.com, brunalcarvalho@hotmail.com (2)Embrapa Café, Parque Estação Biológica, s/no, CEP 70770-901 Brasília, DF, Brazil. E-mail: lilian.padilha@embrapa.br, carlos.carvalho@embrapa.br, mirian.maluf@embrapa.br

\begin{abstract}
The objective of this work was to analyze coffee (Coffea arabica) genotypes resistant to the coffee leaf miner (Leucoptera coffeella) using microsatellite markers. Sixty-six loci were evaluated, of which 63 were obtained from the Brazilian Coffee Expressed Sequence Tag (EST) database. These loci were amplified in bulks of individuals from $\mathrm{F}_{5}$ progenies of 'Siriema' (C. arabica $\mathrm{x}$ C. racemosa) resistant and susceptible to the insect, in eight samples of C. racemosa, and in $\mathrm{F}_{6}$ population of 'Siriema' with 91 individuals segregating for resistance to the leaf miner. Polymorphisms were verified for two simple sequence repeat (SSR) loci in bulks of the susceptible progenies. The two polymorphic alleles were present in around $70 \%$ of the susceptible genotypes in $\mathrm{F}_{5}$ and in approximately $90 \%$ of the susceptible individuals in $\mathrm{F}_{6}$. However, the polymorphic EST-SSR markers among populations contrasting for resistance to leaf miner were not correlated to the evaluated characteristics. SSR markers show inter- and intraspecific polymorphism in C. arabica and C. racemosa.
\end{abstract}

Index terms: Coffea arabica, Leucoptera coffeella, EST-SSR, genotypes.

\section{Marcadores microssatélites na análise de resistência ao bicho-mineiro em café arábica}

Resumo - O objetivo deste trabalho foi analisar genótipos de cafeeiro (Coffea arabica) resistentes ao bicho-mineiro (Leucoptera coffeella), com uso de marcadores microssatélites. Foram avaliados 66 locos, dos quais 63 foram obtidos do banco de sequências expressas (EST) de café. Esses locos foram amplificados em "bulks" de progênies $\mathrm{F}_{5}$ de 'Siriema' (C. arabica x C. racemosa) resistentes e suscetíveis ao ataque da praga, em oito acessos de C. racemosa, e em uma população $\mathrm{F}_{6}$ de 'Siriema' com 91 indivíduos que segregam para resistência ao bicho-mineiro. Os polimorfismos foram verificados em dois locos de marcadores microssatélites (SSR), nos "bulks" das progênies suscetíveis. Os dois alelos polimórficos estiveram presentes em torno de $70 \%$ dos genótipos suscetíveis em $\mathrm{F}_{5}$ e em, aproximadamente, $90 \%$ dos indivíduos suscetíveis em $\mathrm{F}_{6}$. Entretanto, os marcadores EST-SSR polimórficos entre populações contrastantes para a resistência ao bicho-mineiro não foram correlacionados às características avaliadas. Os marcadores SSR apresentam polimorfismo inter e intraespecífico em C. arabica e C. racemosa.

Termos para indexação: Coffea arabica, Leucoptera coffeella, EST-SSR, genótipos.

\section{Introduction}

The coffee leaf miner [Leucoptera coffeella (Guérin-Mèneville)] is considered the main pest in Brazilian coffee plantations. This microlepidoptera reduces the photosynthetic area of leaves, causing large losses in coffee production (Souza et al., 1998). Up to the present, commercial cultivars of Arabica coffee (Coffea arabica L.) registered in Brazil are susceptible to the coffee leaf miner, making chemical control of this pest indispensable. The use of resistant cultivars is an advantageous alternative for the control of biotic stresses. This strategy promotes a greater competitiveness for farmers, since it allows greater yields by reducing losses caused by the attack of pests and diseases, production costs and pollution of the environment by the application of agricultural chemicals.

The Coffea genus has 103 species (Davis et al., 2006) with $2 \mathrm{n}=22$ chromosomes. The exception is $C$. arabica, an allotetraploid, with 44 chromosomes, of which 22 came from $C$. eugenioides $\mathrm{S}$. Moore and the rest from C. canephora Pierre ex A. Froehner (Lashermes et al., 1999). C. arabica has a narrow genetic base due to the small quantity of seeds originally introduced in Brazil associated with the autogamous nature of

Pesq. agropec. bras., Brasília, v.46, n.12, p.1650-1656, dez. 2011 
this species. In addition, the predominance of mass selection and pedigree methods in breeding strategies has also contributed to reduce genetic diversity in C. arabica.

The resistance to L. coffeella in Coffea spp. was identified in the Instituto Agronômico (IAC) coffee breeding program in a fertile plant derived from a natural cross between C. racemosa Ruiz \& Pav. and the Blue Mountain cultivar of $C$. arabica. Hybrid populations obtained from the combination of backcrossing and pedigree methods are established in the field, but these populations are still segregating for this trait (Guerreiro Filho, 2006).

The leafminer resistance introduced from C. racemosa is controlled by two dominant complementary genes, Lm1 and Lm2 (Guerreiro Filho et al., 1999). However, the difficulty in stabilizing this trait in the genotypes indicates the need for more studies. So far, molecular studies of leaf miner resistance did not help to determine the nature of this resistance in Arabica coffee plants (Mondego et al., 2005; Pinto et al., 2007).

Microsatellite or simple sequence repeat (SSR) markers are based on repetitive DNA sequences and occur in the genome of all organisms. These markers are highly variable, and multiallelic genetic loci stand out for codominance and high content of polymorphism information (Tautz \& Renz, 1984; Gupta \& Varshney, 2000; Morgante et al., 2002). Microsatellites can be scored by many methods, which include derivation from enriched genomic libraries and screening of cDNA libraries from public databases, such as GenBank, from related species and from EST (expressed sequence tag) databases. EST-SSR have some intrinsic advantages in that they are quick to elucidate - by electronic sorting -, abundant, unbiased in repeat type and present in gene-rich areas (Scott, 2001). The Brazilian Coffee EST database has more than 200 thousand DNA sequences (Vieira et al., 2006).

The objective of this work was to analyze C. arabica genotypes resistant to the coffee leaf miner (Leucoptera coffeella) using microsatellite markers.

\section{Materials and Methods}

The genetic materials were obtained from the experimental fields of Coromandel and Boa Esperança, MG, Brazil, of the Fundação Procafé and from the Centro de Café of Instituto Agronômico (IAC),
Campinas, SP, Brazil. Molecular analyses were done at the Laboratório de Análise de Sementes e Biotecnologia of the Universidade Federal de Lavras, Lavras, MG, Brazil.

Leaves from the following genetic materials were used: eight $C$. racemosa accessions from the IAC coffee germplasm bank, which were identified as CR1, CR2, CR3, CR4, CR6, CR8, CR9 and CR10; 'Siriema' progenies from the Coromandel coffee field, of which ten were resistant $F_{5}$ progenies (R3, R23, R29, R30, R33, R34, R37, R43, R46 and R49) and ten were susceptible $\mathrm{F}_{5}$ progenies $(\mathrm{S} 1, \mathrm{~S} 4, \mathrm{~S} 8, \mathrm{~S} 13$, S15, S21, S24, S38, S42 and S48) - each progeny was composed of ten plants -; and $91 \mathrm{~F}_{6}$ 'Siriema' plants from Boa Esperança, MG, Brazil. This population was used to evaluate segregating loci that were detected in $\mathrm{F}_{5}$ progenies.

After the $C$. arabica x $C$. racemosa cross, the material passed through two backcrossings with C. arabica at IAC, and the segregant IAC 1195-5-6-2 was selected. C1195-5-6-2-119, with high resistance to coffee leaf miner, was selected by the Procafé breeding program and crossed with 'Catimor UFV 417' to incorporate rust resistance. From this cross, segregant 842 was selected, with resistance to rust and to leaf miner. Plants 842-1 and 842-4, designated 'Siriema', were advanced in their generations by the pedigree method, and currently are in the $\mathrm{F}_{5}$ generation (Carvalho et al., 2008).

The 'Siriema' $F_{5}$ progenies were in the field for five years under evaluation for tolerance to the coffee leaf miner. The $\mathrm{F}_{6}$ population was characterized at the IAC greenhouse (Guerreiro Filho et al., 1999). Lesion reaction was observed in leaf disks infested by L. coffeella, according to four classes: resistant, plants with point lesions; moderately resistant, plants with small threadlike lesions; moderately susceptible, plants with large threadlike lesions; and susceptible, plants with large irregular lesions.

Thirty-five EST-SSRs di- and trinucleotides, already available in the EST Coffee Genome database, were selected as a strategy to increase the possibility of obtaining polymorphic markers. These EST-SSR are more polymorphic than tetra-, penta- or hexanucleotides (Poncet et al., 2004). Information about the library, repetition patterns and the frequency of repetitions were extracted from the database (Table 1). Parameters for primer design considered 54 to $65^{\circ} \mathrm{C}$ melting 
temperature (Tm) and 40 to 50\% CG bases; amplicons ranged from 100 to 300 nucleotides; and primers had 18 to 22 bases (Table 2 ).

In addition, 28 EST-SSR primers (Pinto et al., 2007) and three more SSR loci, already characterized for coffee biotic stress (Herrera et al., 2009), were used: Sat 225 (F: 5'CAT GCC ATC ATC AAT TCC AT3'; R: 5'TTA CTG CTC ATC ATT CCG CA3'), Sat 229 (F: 5'TTC TAA GTT GTT AAA CGA GAC GCT TA3'; R: 5'TTC CTC CAT GCC CAT ATT G3')

Table 1. EST-SSR loci selected from the EST Coffee Genome database.

\begin{tabular}{|c|c|c|c|c|c|c|}
\hline Locus & $\begin{array}{l}\text { Genomic } \\
\text { library }^{(1)}\end{array}$ & Motif & $\begin{array}{l}\text { Repetition } \\
\text { frequency }\end{array}$ & $\begin{array}{l}\text { Expected } \\
\text { size (bp) }\end{array}$ & $\begin{array}{l}\text { Observed } \\
\text { size }(b p)\end{array}$ & $\begin{array}{c}\text { Number of } \\
\text { alleles }\end{array}$ \\
\hline$\overline{\text { LEG1 }}$ & CL2, PA1 & GA & 21.5 & 222 & $180-200 ; 600$ & 3 \\
\hline LEG2 & AR1 & $\mathrm{AC}$ & 15.5 & 226 & $180-220$ & 2 \\
\hline LEG3 & FB1, FR2 & AT & 26.0 & 379 & 200 & 3 \\
\hline LEG4 & AR1, LV9, RX1 & AT & 26.0 & 250 & -(2) & - \\
\hline LEG5 & LV9, LP1, SS1 & AT & 80.0 & 599 & $210-500$ & 4 \\
\hline LEG6 & CL2 & $\mathrm{TA}$ & 15.0 & 200 & - & - \\
\hline LEG7 & RT8, CS1, RX1 & $\mathrm{TC}$ & 15.5 & 237 & - & - \\
\hline LEG8 & FB1, LP1 & GAG & 16.7 & 218 & - & - \\
\hline LEG9 $^{(3)}$ & FB4 & GAT & 19.0 & 235 & $120-230$ & 4 \\
\hline LEG10 & LV9 & $\mathrm{AG}$ & 15.0 & 228 & 230 & 1 \\
\hline LEG11 ${ }^{(3)}$ & BP1, CB1, EA1, EB1, EM1, FR4, IC1, RX1, S13, RM1 & TGG & 27.3 & 281 & $150-200$ & 2 \\
\hline LEG12(3) & BP1, LV5, S13 & $\mathrm{TC}$ & 20.5 & 223 & $150-210$ & 3 \\
\hline $\mathrm{LEG} 3^{(3)}$ & EM1, S13, SH2 & GAA & 18.0 & 249 & $150-300$ & 3 \\
\hline LEG14 & RX1, FR1 & AT & 20.5 & 210 & $150-180$ & 2 \\
\hline LEG15 & CL2 & CT & 16.5 & 216 & $200-350$ & 4 \\
\hline LEG16 & CL2, FB2, LV5, RT5, RX1 & CA & 27.5 & 244 & - & - \\
\hline LEG17 & FB4, PC1 & $\mathrm{CT}$ & 22.0 & 190 & $130-180$ & 2 \\
\hline LEG18 & CL2, EA1, FR1, S13, RX1 & GCT & 10.7 & 249 & $250-300$ & 2 \\
\hline LEG19 & CB1, CS1, FB1, FR2, IA2, LV5, LV9, RT5, RX1 & GAA & 22.0 & 291 & $150-350$ & 4 \\
\hline LEG20 & CS1, FB1, LV5, RX1, RM1 & TA & 22.0 & 282 & $180-300$ & 2 \\
\hline LEG21 & $\mathrm{EA} 1, \mathrm{~S} 13, \mathrm{SH} 2$ & AGG & 14.0 & 290 & $160-290$ & 2 \\
\hline LEG22(3) & EA1 & $\mathrm{TC}$ & 21.5 & 286 & 300 & 1 \\
\hline LEG23 & CA1, RT8, FR4, EA1, RX1, S13 & GA & 23.0 & 218 & - & - \\
\hline LEG24 & CA1, FR2, FB1, FB2, BP1, CB1, EA1, IA2, LP1, PA1, S13, SH3, FV2 & $\mathrm{TC}$ & 27.0 & 176 & 300 & 1 \\
\hline LEG25 & LV5, CL2, CB1, IA2 & AT & 17.5 & 183 & $270-300$ & 2 \\
\hline LEG26 $(3)$ & $\mathrm{CS} 1$ & ATA & 12.7 & 197 & $190-230$ & 2 \\
\hline LEG27 & FB1, CB1 & TA & 20.0 & 231 & $180-300$ & 3 \\
\hline LEG28 $8^{(3)}$ & BP1, FR4, RT3 & AGT & 11.0 & 250 & $250-280$ & 3 \\
\hline LEG29 & CA1, CL2, CS1, EA1, FR2, FR4, S13, SH2 & $\mathrm{AG}$ & 16.0 & 163 & $170-200$ & 2 \\
\hline LEG30 & LV5 & CTG & 19.0 & 239 & $240-320$ & 2 \\
\hline LEG31 & AR1, CS1, LV5, S13 & $\mathrm{CCT}$ & 13.3 & 247 & 250 & 1 \\
\hline $\mathrm{LEG}^{2} 2^{(3)}$ & CS1, RX1, S13 & AGA & 19.0 & 214 & $210-300$ & 3 \\
\hline LEG33 & CS1, RT8 & $\mathrm{AG}$ & 56.0 & 219 & - & - \\
\hline LEG34 & $\mathrm{CS} 1, \mathrm{FR} 4$ & $\mathrm{TA}$ & 25.5 & 212 & $200-280$ & 3 \\
\hline LEG35 & BP1, CB1, CS1, FR4, IC1, RX1, S13, RM1 & AT & 23.5 & 210 & - & - \\
\hline
\end{tabular}

${ }^{(1)} \mathrm{CA} 1$, non embryogenic callus; LV5, pointer leaf - orthotropic branch without Bion - short; LV9, pointer leaf - plagiotropic branches without Bion - short; RT3, root without Bion; RT5, root with Bion; CL2, hypocotyl callus with and without Bion; FR1, flower bud no. 6, lead no. 1, fruit stage 1 and 2 - long; FR2, flower bud no. 6, lead no. 1, fruit stage 1 and 2 - short; FB1, flower bud stage 1 and 2 - long; FB2, flower bud stage 1 and 2 - short; FB4, flower bud stage 3 and 4; RT8, root and cells in suspension with aluminum; BP1, cells in suspension, root and leaf with Bion; RM1, leak infested with coffee leaf miner and rust; $\mathrm{CB} 1$, cells in suspension with Bion and brassinosteroids; CS1, cells in suspension with mannose, $\mathrm{NaCl}$ and $\mathrm{KCl}$; FR4, racemosa fruits; EA1, embryogenic callus of Coffea arabica; EB1, zygotic embryo (immature fruits); IC1, non embryogenic progeny (C. arabica leaf) without induction of 2.4D; PC1, non embryogenic progeny (C. arabica leaf) with induction of 2.4D; IA2, embryogenic progeny (C. arabica leaf) with induction of 2.4D; AR1, leaves treated with arachidonic acid; LP1, seedlings treated with arachidonic acid; RX1, branches infected with Xylella spp.; PA1, embryogenic progeny (C. arabica primary callus); S13, seeds at the beginning of germination; SH2, water stress in the field (tissue pool - leaves, branches, gemmae, etc.); SH3, water stress in the field (C. canephora clone tolerant to drought); FV2, leaf stage 1, 2 and 3 (C. racemosa); SS1, irrigated in the field (tissue pool - leaves, branches, gemmae, etc.); EM1, embryo (seed). ${ }^{(2)}$ Não houve amplificação. ${ }^{(3)}$ Polymorphic loci. 
and Sat 259 (F: 5'GCC AAT TGT GCA AAG TGC T-3'; R: 5'ATT CAT GGG GCC TTT GTC TT3').

All the primers were screened in the C. racemosa and $\mathrm{F}_{5}$ progenies. The polymorphic oligonucleotides were used to amplify DNA fragments of each individual of the $\mathrm{F}_{5}$ progenies and of the $\mathrm{F}_{6}$ individuals of the population. Genomic DNA was extracted according to Ferreira \& Grattapaglia (1996) by the CTAB 2\% method. Final reaction conditions were 1X PCR buffer (Tris-HCl, $200 \mu \mathrm{mol} \mathrm{mL} \mathrm{m}^{-1} ; \mathrm{pH}$ 8.4; KCl, $\left.500 \mu \mathrm{mol} \mathrm{mL} L^{-1}\right) ; 2 \mu \mathrm{mol} \mathrm{mL}^{-1}$ of $\mathrm{MgCl}_{2} ; 400 \mathrm{nmol} \mathrm{mL}^{-1}$ of dNTPs; $0.3 \mathrm{nmol} \mathrm{mL} \mathrm{m}^{-1}$ of each primer; $0.5 \mathrm{U}$ of DNA Taq polymerase; and $30 \mathrm{ng}$ of DNA. The PCR cycles were: $94^{\circ} \mathrm{C}$, for $3 \mathrm{~min}$, followed by 30 cycles of $94^{\circ} \mathrm{C}$ for $1 \mathrm{~min}$; annealing temperature from 55 to $57^{\circ} \mathrm{C}$ for $1 \mathrm{~min}$, in touchdown, $72^{\circ} \mathrm{C}$, for $1 \mathrm{~min}$, and final extension, at $72^{\circ} \mathrm{C}$, for $5 \mathrm{~min}$. Amplified products were separated through polyacrylamide gel electrophoresis.

Number and size of SSR amplification products were characterized. Qualitative analyses based on the presence or absence of SSR alleles were performed for characterization of polymorphism between segregating materials.

\section{Results and Discussion}

Thirty-five EST-SSR sequences were selected among 77 EST-SSR analyzed in 3,388 sequences expressed in different libraries from the ESTCoffeeGenome database (Table 1). In this database, the trinucleotides were the

Table 2. EST SSR primers designed from contigs available in the coffee EST database.

\begin{tabular}{|c|c|c|c|}
\hline Locus & Contig & \multicolumn{2}{|c|}{ Primer sequence $\left(5^{\prime}-3^{\prime}\right)$} \\
\hline LEG1 & 6239 & F: GTG GCC AGT TGA GTT GCA TA & R: GAG ATG AGA TGG GCT TCT TGA \\
\hline LEG2 & 846 & F: GGA CAA AGA CGC CTA ATC CA & R: CCG TTG CAT GAT AAA CGA CA \\
\hline LEG3 & 2664 & F: GGA TAT CGC ATC AGC CTC TC & R: AGC GGT TTC TTT CTT TG \\
\hline LEG4 & 2796 & F: CCT TTG AGG TGG TCA GCC TA & R: AGA GAA CCC AGG GTC AAG TTT A \\
\hline LEG5 & 4345 & F: GTC CAT TAG GCA TTT GTT GC & G: CTG GCC GCT AAA GAT AAG TAG A \\
\hline LEG6 & 7115 & F: GGT TTA CCC CAT GAG AGC AG & R: CTT GTG CTT GAG CCA TTT CA \\
\hline LEG7 & 8478 & F: CGA GGA GTT GAT TGC TGG A & R: TTC GAG TGA AAT CCC AAT CC \\
\hline LEG8 & 8911 & F: ACG GAA GAG GCA GAG ACT GA & R: CTT CCT TGG ACC CTC ATC AA \\
\hline LEG9 & 10226 & F: AGG TTT CCA AAG GAG ATG AGC & R: GAA GAC AAG TCC ATC GTC CAA \\
\hline LEG10 & 10393 & F: CAT GAT CAA CCC AAC AGC AT & R: TGA ATG TGT ATC GGG AGC AG \\
\hline LEG11 & 11764 & F: CAC TGA AGG CCT GGA AGA AT & R: AGC ATC TGC AGC CTC CAT AG \\
\hline LEG12 & 13870 & F: CAC CAT AGC AAC TTC AAA CAC G & R: CAC ATC CAG GAA CCT TGC TC \\
\hline LEG13 & 14035 & F: GAA GAG GAA GAA GGG GCA AG & R: GTG GTG GAG GAA AGG GAT TC \\
\hline LEG14 & 1174 & F: AGA GCC CCT TCT CGC TAT GT & R: GTT AAC GCC GGA TAT GCT TC \\
\hline LEG15 & 2291 & F: TCT ATG CAC ACC CTC CAC AA & R: AGC ATT GGT TTG CTT CTT GC \\
\hline LEG16 & 2913 & F: CTG CTT GTT GGC CAT AAT GA & R: ACA GTG GAA GAA GGC GAG AG \\
\hline LEG17 & 10221 & F: TGC GAC ATT TCA CTC TGC AT & R: GCC TAT GTT GTG TAC GTG TGC \\
\hline LEG18 & 1177 & F: CAA ACA ATG GTG ACG TGC TC & R: CAA GGC CAG CGA AAA AGA T \\
\hline LEG19 & 3388 & F: GTT GCC GTC TTC AGC TCT TC & R: CAT TGG AAT TGT TGC TGG TG \\
\hline LEG20 & 3982 & F: ATC TGC AAC GAA AGC TGG AG & R: GGC TTT CCT TTG ACA ACT GG \\
\hline LEG21 & 5374 & F: GGA TGA TGG AAA AGC GAA TG & R: GGC CAA GTA GAG AGT GAT TTG C \\
\hline LEG22 & 5376 & F: CTT CAT CTC CCT GCC AAC AC & R: TCT TCT AAG GCC AGC AAG GA \\
\hline LEG23 & 6480 & F: ACA GCA GGG GAA GAG TGT GT & R: CCC AAT CTA AGC CCC TGA AT \\
\hline LEG24 & 6708 & F: CGT AGG CGA ACC AAA AAC TT & R: CAG GAC CCA AGG TCA CAT TC \\
\hline LEG25 & 7368 & F: CGA AGA CGA AGC ACC AAG AT & R: TAA TGG GTT CAA CCG GAG TC \\
\hline LEG26 & 7797 & F: TGA AGC TGC CTC CTG TTT CT & R: CGT CAG CTC AAG AAC TGT GC \\
\hline LEG27 & 7861 & F: ATA GAT TCC AGC GGA AAG CA & R: TGC TCC ACA CCA CTG CTA AC \\
\hline LEG28 & 10553 & F: TGT TCA CAG CTA AAC CCA ACC & R: TTG ACG GTG ACG ATG TTG AT \\
\hline LEG29 & 11836 & F: TGG CTT CCT TGA TGC TTT CT & R: TGT GAT GGA ACG CGA ATA TG \\
\hline LEG30 & 12228 & F: TTG CCA TGT TTC CCA TAC CT & R: CAA AGA TCA CCC CTC ATG CT \\
\hline LEG31 & 13778 & F: ACT ATT GCT CCC CCG GTA TC & R: GAC TCG GAG AAC ACG TTG GA \\
\hline LEG32 & 13853 & F: GGG TGA TGG AAA AGC AAA TG & R: CCA GCA TCA GCA AGT AAA AGG \\
\hline LEG33 & 11356 & F: TGT GAA AAA GCC TCG AGT GA & R: TAA CAC GAG GGA GGG AGA GA \\
\hline LEG34 & 11478 & F: GCA AAC TTG TGG CTG ATC G & R: ATC AAA CGC ACC CTG ACA TT \\
\hline LEG35 & 11696 & F: CCG ATG CTT CCC TAT TTC CT & R: CTC TTT GTG GCC ATC GAT CT \\
\hline
\end{tabular}


most abundant (39.02\%), followed by di- (35.83\%), tetra- $(1.65 \%)$, hexa- $(0.79 \%)$ and pentanucleotides $(0.38 \%)$. The presence of mononucleotides was also significant $(22.19 \%)$; however, these microsatellites are not greatly used since they have low polymorphism. In silico EST analyses performed on leaves and fruits of C. canephora (Poncet et al., 2004) showed that the trinucleotide microsatellites are also the most abundant, followed by the di- and hexanucleotides, representing $34.34,25.75$ and $22.04 \%$, respectively. The significant presence of mononucleotides was also reported.

In comparison with some of the other approaches, EST-SSR may be slightly less polymorphic than genomic library-derived SSR, as there is pressure for sequence conservation in gene regions, reducing polymorphism (Scott, 2001). Selection of EST-SSRs with tri- and dinucleotide motifs was preferred to increase the probability of polymorphic EST markers being identified. Out of the 35 EST-SSR loci randomly selected, fragment amplification was detected in 27 . Among these, eight loci were polymorphic, 18 were monomorphic, and, in the others, amplification was not observed or they showed diffuse bands (Table 1).

A total of 63 alleles were amplified and their sizes varied from 120 to $350 \mathrm{bp}$. These alleles showed amplified fragments with the expected size. The exception was LEG1 that amplified an allele with 600 bp that could be related to an intron. In most loci, two alleles were detected, but loci with three or four alleles were also found, which is expected for tetraploid species, such as C. arabica.

The LEG9, LEG11, LEG12, LEG13, LEG22, LEG26, LEG28 and LEG32 loci were polymorphic only among $C$. racemosa accessions and $C$. arabica progenies. Therefore, genetic variability is expected between these two species. Poncet et al. (2004) also observed EST-SSR polymorphism between
C. canephora for six species of Coffea; C. eugenioides S. Moore, C. heterocalyx Stoff., C. liberica W. Bull ex Hiern, C. dewevrei De Wild. \& T. Durand, Coffea sp. Moloundou and C. pseudozanguebariae Bridson. The search for polymorphic SSR loci associated with a desirable trait is complex due to the limited number of coffee SSRs available. In species with a narrow genetic base, such as $C$. arabica, the probability of finding polymorphism is low (Baruah et al., 2003; Vieira et al., 2006). Genetic diversity among coffee species identified by EST-SSR markers can be used as a gene source in breeding programs, with potential for other studies of genetic mapping, in the identification of cultivars or in pre-breeding by the genotyping of germplasm bank accessions.

Polymorphism among the susceptible and resistant genotypes to the coffee leaf miner was observed in loci Sat 225 and Sat 229. The Sat 259 locus was monomorphic in all the evaluated genotypes. The amplification profile of the Sat 225 locus corresponds to a $300 \mathrm{bp}$ allele (Figure 1). This allele was present in both susceptible and resistant bulks and also in $C$. racemosa accessions. As the C. racemosa parent no longer exists, a bulk of accessions from the IAC germplasm bank was used to represent the genetic diversity of this species. However, no polymorphic alleles associated with resistance to coffee leaf miner were detected. Another allele with approximately 270 bp was verified in the susceptible progenies (S4, S8, S15, S21, S24, S38, S42 and S48). For the Sat 229 primer, a $190 \mathrm{bp}$ polymorphic allele was observed in the individuals of the S4, S8, S15, S21, S38 and S42 bulks.

After screening, bulks were opened and both Sat 225 and Sat 229 were evaluated in individuals from the $\mathrm{F}_{5}$ Coromandel progenies. The Sat 225 amplification pattern was the same as that shown in

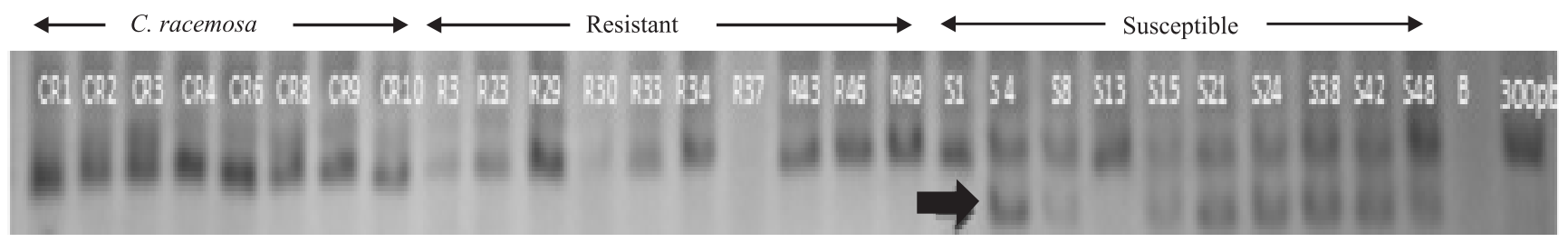

Figure 1. Amplification of the SSR Sat 225SSR Sat 225 locus in Coffea racemosa (CR1, CR2, CR3, CR4, CR6, CR8, CR9, CR10), bulks of resistant plants (R3, R23, R29, R30, R33, R34, R37, R43, R46, R49) and susceptible plants (S1, S4, S8, S13, S15, S21, S24, S38, S42, S48) to coffee leaf miner. The arrow indicates the 270 bp polymorphic band, found in the bulk of susceptible individuals 
the bulks. The $270 \mathrm{bp}$ allele, potentially associated with susceptibility to the coffee leaf miner, was present in $73 \%$ of the susceptible individuals and absent in $91 \%$ of the resistant individuals. Likewise, the 190 bp polymorphic allele from locus Sat 229 was observed in $70 \%$ of the susceptible individuals and absent in $94 \%$ of the resistant ones. According to Carvalho et al. (2008), a 30 to $40 \%$ of susceptibility to L. coffeella in 'Siriema' $\mathrm{F}_{5}$ progenies is commonly observed in the field.

The $\mathrm{F}_{6}$ population was characterized by the evaluation of lesions in the infested leaf disks. A total of 37 individuals were classified as resistant and 54 as susceptible to the insect. Molecular characterization shows that the $270 \mathrm{bp}$ polymorphic allele from the Sat 225 locus was found in $91 \%$ of the susceptible genotypes and was absent in $36 \%$ of the resistant ones. The 190 bp polymorphic allele from locus Sat 229 was observed in $91 \%$ of the susceptible individuals and in $48 \%$ of the resistant ones. Although a high amplification frequency is observed in susceptible genotypes, both 270 bp (Sat 225) and 190 bp (Sat 229) alleles were observed in resistant genotypes. However, no significant correlation among the molecular markers and the presence of lesions in coffee leaves infested by L. coffeella was detected.

Herrera et al. (2009) evaluated the Sat 225 and Sat 229 loci in a $F_{2}$ segregating population resulting from a cross between the susceptible $C$. arabica cultivar Caturra and the resistant female parental hybrid derived from the cross between C. arabica and C. canephora. These authors observed the occurrence of a variable amplification pattern during the evaluated years, which may be associated with the infestation pressure of the pathogen. Genetic analysis indicates that the two loci could be associated with leaf-rust resistance and that the additive effect would be essential for the expression of resistance.

In the present work, alleles associated with resistance to the coffee leaf miner were not identified. The frequency of plants with resistance in segregating populations has not increased, remaining near 35\%, although some families show a higher percentage. The genetic control of resistance to the coffee leaf miner appears to be more complex. Therefore, other factors, besides the control determined by the two genes, as mentioned by Medina Filho (1977) and Guerreiro Filho et al. (1999), may be involved.
The use of markers as tools to assist coffee breeding programs may contribute to save time for the development of new cultivars. However, the coffee molecular markers presently available have shown limited polymorphism. Several strategies for the development of new coffee molecular markers, such as diversity arrays technology (DArTs) (Wittenberg et al., 2005) and single nucleotide polymorphism (SNPs), identified through comparative genomics or re-sequencing, using new generation sequencing, will certainly contribute to the development of more informative markers, which may be used to map valuable traits in a more precise manner.

\section{Conclusions}

1. SSR markers show inter- and intraspecific polymorphism in Coffea arabica and C. racemosa.

2. No polymorphic alleles are associated with resistance to coffee leaf miner in the evaluated SSR loci.

\section{Acknowledgements}

To Fundação Procafé and Instituto Agronômico, for supplying the genetic material and for support in carrying out the research; to Consórcio Brasileiro de Pesquisa do Café, Conselho Nacional de Desenvolvimento Científico e Tecnológico and Fundação de Amparo à Pesquisa do Estado de Minas Gerais, for financial support.

\section{References}

BARUAH, A.; NAIK, V.; HENDRE, P.S.; RAJKUMAR, R.; RAJENDRAKUMAR, P.; AGGARWAL, R.K. Isolation and characterization of nine microsatellite markers from Coffea arabica L., showing wide cross-species amplifications. Molecular Ecology Notes, v.3, p.647-650, 2003.

CARVALHO, C.H.S. de; FAZUOLI, L.C.; GUERREIRO FILHO, O.; PEREIRA, A.A.; ALMEIDA, S.R. de; MATIELLO, J.B.; BARTHOLO, G.F.; SERA, T.; MOURA, W. de M.; MENDES, A.N.G.; REZENDE, J.C. de; FONSECA, A.F.A. da; FERRAO, M.A.G.; FERRÃO, R.G.; NACIF, A. de P.; SILVAROLLA, M.B.; BRAGHINI, M.T. Cultivares de café arábica de porte baixo. In: CARVALHO, C.H.S. de (Ed.). Cultivares de café: origem, características e recomendações. Brasília: Embrapa Café, 2008. p.157-226.

DAVIS, A.P.; GOVAERTS, R.; BRIDSON, D.M.; STOFFELEN, P. An annotated taxonomic conspectus of the genus Coffea (Rubiaceae). Botanical Journal of the Linnean Society, v.152, p.465-512, 2006. 
FERREIRA, M.E.; GRATTAPAGLIA, D. Introdução ao uso de marcadores moleculares em análise genética. 2.ed. Brasília: Embrapa-Cenargen, 1996. 220p. (Embrapa-Cenargen. Documentos, 20).

GUERREIRO FILHO, O. Coffee leaf miner resistance. Brazilian Journal of Plant Physiology, v.18, p.109-117, 2006.

GUERREIRO FILHO, O.; SILVAROLLA, M.B.; ESKES, A.B. Expression and mode of inheritance of resistance to leaf miner Perileucoptera coffeella. Euphytica, v.105, p.7-15, 1999.

GUPTA, P.K.; VARSHNEY, R.K. The development and use of microsatellite markers for genetic analysis and plant breeding with emphasis on bread wheat. Euphytica, v.113, p.163-185, 2000.

HERRERA, J.C.P.; ALVARADO, G.A.; CORTINA, H.A.G.; COMBES M.; ROMERO, G.G.; LASHERMES, P. Genetic analysis of partial resistance to coffee leaf rust (Hemileia vastatrix Berk $\&$ Br.) introgressed into the cultivated Coffea arabica L. from the diploid C. canephora species. Euphytica, v.167, p.57-67, 2009.

LASHERMES, P.; COMBES, M.C.; ROBERT, J.; TROUSLOT, P.; D'HONT, A.; ANTHONY, F.; CHARRIER, A. Molecular characterisation and origin of the Coffea arabica L. genome. Molecular and General Genetics, v.261, p.259-266, 1999.

MEDINA FILHO, H.P.; CARVALHO, A.; MEDINA, D.M. Germoplasma de Coffea racemosa e seu potencial de melhoramento do cafeeiro. Bragantia, v.36, p.43-46, 1977.

MONDEGO, J.M.C.; GUERREIRO FILHO, O.; BENGTSON, M.H.; DRUMMOND, R.D.; FELIX, J.M.; DUARTE, M.P.; RAMIRO, D.A.; MALUF, M.P.; SOGAYAR, M.C.; MENOSSI, M. Isolation and characterization of Coffea genes induced during coffee leaf-miner (Leucoptera coffeella) infestation. Plant Science, v.169, p.351-360, 2005.
MORGANTE, M.; HANAFEY, M.; POWELL, W. Microsatellites are preferentially associated with nonrepetitive DNA in plant genomes. Nature Genetics, v.30, p.194-200, 2002.

PINTO, F. de O.; MALUF, M.P.; GUERREIRO FILHO, O. Study of simple sequence repeat markers from Coffea expressed sequences associated to leaf miner resistance. Pesquisa Agropecuária Brasileira, v.42, p.377-384, 2007.

PONCET, V.; HAMON, P.; MINIER, J.; CARASCO, C.; HAMON, S.; NOIROT, M. SSR cross-amplification and variation within coffee trees (Coffea spp.). Genome, v.47, p.1071-1081, 2004.

SCOTT, K.D. Microsatellite derived from ESTs, and their comparison with those derived by other methods. In: HENRY, R.J. (Ed.). Plant genotyping: the DNA fingerprinting of plants. Oxon: CABI, 2001. p.225-238.

SOUZA, J.C. de; REIS, P.R.; RIGITANO, R.L. de O. Bicho-mineiro do cafeeiro: biologia, danos e manejo integrado. 2.ed. Belo Horizonte: Epamig, 1998. 48p. (Epamig. Boletim técnico, 54).

TAUTZ, D.; RENZ, M. Simple sequences are ubiquitous repetitive components of eukaryotic genomes. Nucleic Acids Research, v.12, p.4127-4138, 1984.

VIEIRA, E.S.N.; ANDRADE, A.C.; COLOMBO, C.A. et al. Brazilian coffee genome project: an EST-based genomic resource. Brazilian Journal of Plant Physiology, v.18, p.95-108, 2006.

WITTENBERG, A.H.J.; LEE, T. van der; CAYLA, C.; KILIAN, A.; VISSER, R.G.F.; SCHOUTEN, H.J. Validation of the high-throughput marker technology DArT using the model plant Arabidopsis thaliana. Molecular Genetics and Genomics, v.274, p.30-39, 2005.

Received on June 16, 2011 and accepted on November 9, 2011

Pesq. agropec. bras., Brasília, v.46, n.12, p.1650-1656, dez. 2011 